\title{
MICROPALAEONTOLOGY NOTEBOOK Tubicolous polychaetes as substrates for epizoic foraminifera
}

\author{
MARTIN R. LANGER \& HARMEET BAGI \\ Museum of Paleontology and Department of Integrative Biology, University of California, Berkeley, CA 94720, USA
}

Associations of epizoic foraminifera and invertebrates are widespread and have been reported from polar to tropical and shallow to bathyal environments (Zumwalt \& DeLaca, 1980). Their fossil record stretches far back into Palaeozoic times as documented by agglutinated foraminifera attached to crinoids in Silurian and Devonian reef deposits of Morocco and Gotland (Franzen, 1974). Strong preferences for filter-feeding hosts suggest that epizoic foraminifera benefit from increased nutritional resources accumulated in the immediate flow microhabitat (Langer \& Long, 1994).

In the course of a broader study on foraminifera/invertebrate associations, several hundred foraminifera attached to the outer wall of agglutinated tubes of various polychaetes (e.g. Sabella sp., Potamilla sp.) were collected from sediment samples dredged at $61 \mathrm{~m}$ depth off the University of California, Moss Landing Marine Laboratory (NW Pacific). Attached foraminifera display a remarkable mode to obtain and differentially cement grains from the host tube that previously has not been reported. Agglutinated polychaete tubes and fragments thereof may reach $2 \mathrm{~cm}$ or more in length and are composed of fine sand, silt and micas cemented together by secreted organic material (Fig. 1). Tubes are typically orientated vertically in the mud and project above the sediment surface into the water column.

\section{NEW OBSERVATIONS}

Examination of agglutinated polychaete tubes revealed that their outer walls were commonly colonized by one to three foraminiferans (Figs 1-3, tube diameter $1.5-2.0 \mathrm{~mm}$ ). The epizoic foraminiferal fauna comprised exclusively agglutinated taxa and included the following species: Alveophragmium advenum (Cushman), Textularia abbreviata Lalicker \& McCulloch, Textularia schencki Cushman \& Valentine, and Goesella flintii, Cushman. All epizoic foraminifera were found to be attached by a combination of secreted and foreign material that is indistinguishable from the composition of the agglutinated host tube (Figs 1,2). Constrictions and thinning at the epizoan attachment site indicate that mineral grains were often recruited from agglutinated polychaete tubes and reutilized in the foraminiferal attachment cement (Figs 2, 3). Agglutinated polychaete tube walls, however, were not found to be penetrated by the epizoans suggesting a commensal, rather than a parasitic, relationship.

No indications of preferential site selection, aggregated distribution patterns, or ecophenotypic responses were observed among the attached foraminifera and the epizoans appear to be randomly distributed on the tube walls. Attached foraminifera, however, were commonly found to leave larger parapore-like openings within the attachment cement (Figs 1-3, arrowed). They are apparently utilized as communication channels for the outside deployment of reticulopods and to access potential food resources in the adjacent surrounding environment.

\section{ACKNOWLEDGEMENTS}

We thank James Nybakken of the Moss Landing Marine Laboratories for assisting in making arrangements for the collection of sample material.

\section{Manuscript received September 1994} Manuscript accepted September 1994
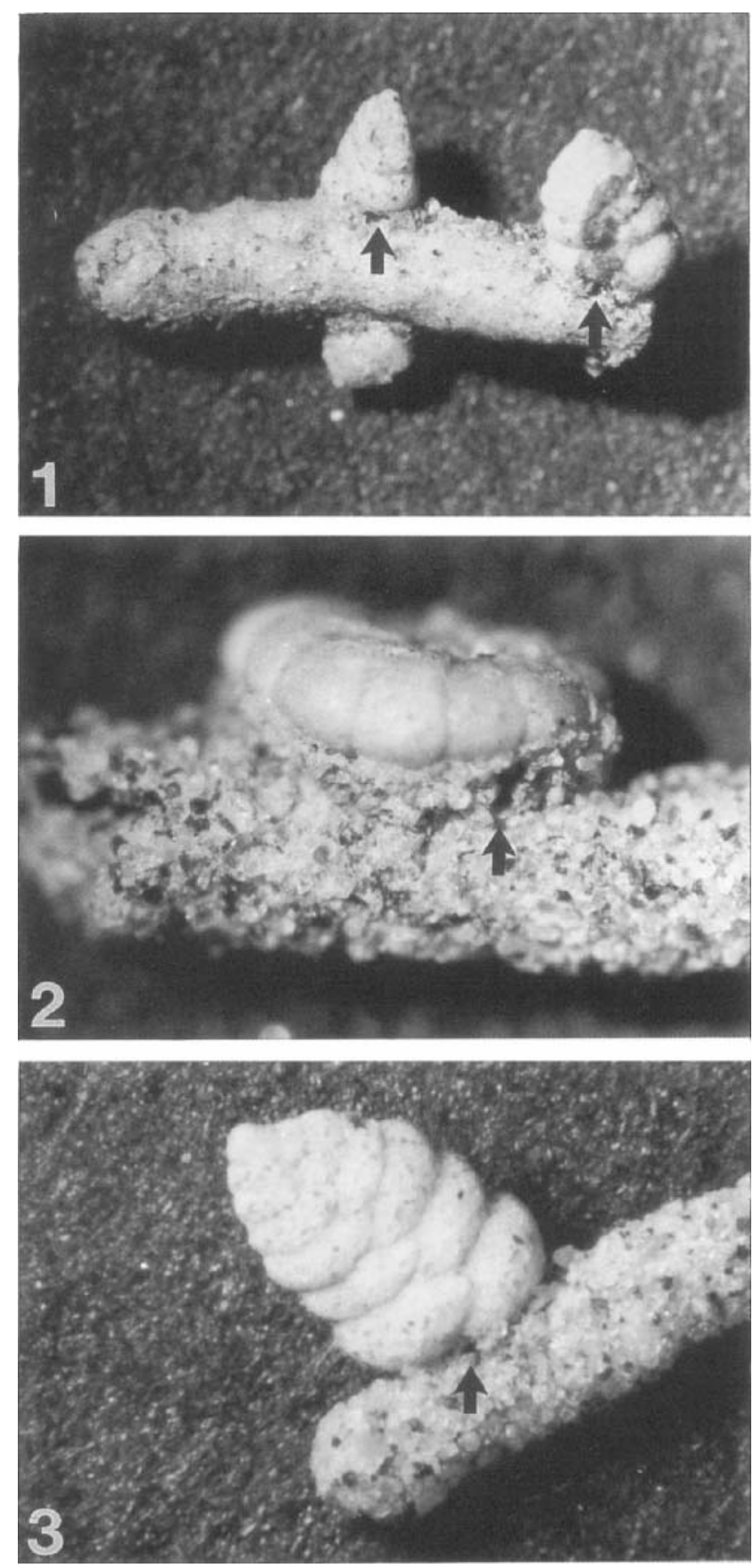

Fig. 1-3.

\section{REFERENCES}

Franzen, C. 1974. Epizoans on Silurian-Devonian crinoids. Lethaia, 7: 287-301.

Langer, M. R. \& Long, D. J. 1994. Association of benthic foraminifera with a gammarid amphipod on tidal flats of San Francisco Bay, California. Iournal of Coastal Research, 10: $877-883$

Zumwalt, G. S. \& DeLaca, T. E. 1980 . Utilization of brachiopod feeding currents by epizoic foraminifera. Joumal of Paleontology, 54: 477-484. 